\title{
GENETIC STUDIES ON $\alpha$-AMYLASE ISOZYMES IN WHEAT. III. INTRASPECIFIC VARIATION IN AEGILOPS SQUARROSA AND BIRTHPLACE OF HEXAPLOID WHEAT ${ }^{1)}$
}

\author{
KOZO NISHIKAWA, YOSHIHIKO FURUTA AND TAKUO WADA \\ Faculty of Agriculture, Gifu University \\ Kakamigahara, Gifu 504
}

Received May 6, 1980

\begin{abstract}
Fifty seven strains of KUSE (Kyoto University Scientific Expedition to The Karakoram and Hindukush) collection and three laboratory strains of Aegilops squarrosa were examined with respect to $\alpha$-amylase isozymes of germinating seed. Seven zymogram patterns were identified, each of which consisted of a few isozyme bands most probably specified by the genes on chromosome $6 \mathrm{D}$ and only one by the gene on chromosome 7D. Among varieties of Ae. squarrosa, var. typica was most variable, followed by var. strangulata. Variation in $\alpha$-amylase isozymes, as in the other various characters, was most concentrated in the region of Gorgan, in decreasing order being the regions of Pahlavi, Tabriz and Tehran, and no variation in the other regions. From comparison of the zymograms between tetra- and hexaploid wheat, a particular zymogram pattern of $\alpha$-amylase, Ams 3 was concluded as the one expected in the $\mathrm{D}$ genome donor to the main line of descent of hexaploid wheat. Ams 3 located most predominantly in the region of Gorgan, extending westwards along the south coast of Caspian sea up to Derbent, Caucasus. Therefore, it is most reasonable to consider that birthplace of hexaploid wheat should be extended to the south-east coast-land of Caspian sea from the area including south-west Caspian coast region and Transcaucasus, which the previous authors have indicated. On the other hand, discussion about independent origin of ssp. macha was made in view of the variant zymogram pattern.
\end{abstract}

\section{INTRODUCTION}

Aegilops squarrosa, a wild and weedy grass well known as the D genome donor to hexaploid wheat, is an object to which deep and abiding interests of wheat cytogeneticists, either theoretical and practical, have centered. Taxonomically after Eig,

1) Contribution from Laboratory of Genetics and Plant Breeding, Faculty of Agriculture, Gifu University, No. 52. 
this diploid species is classified into two subspecies, i.e. ssp. eu-squarrosa and ssp. strangulata. The former includes three varieties, vars. typica, anathera and meyeri, while the latter only one, var. strangulata. According to Zohary et al. (1969), its primary habitats locate in the narrow belt along the south coast of Caspian sea, extending eastwards to northern Iran, Turkmenistan and northern Afghanistan, where diversity and abundance of this species are conspicuous. From this belt, it reaches to Turkish border, Transcaucasus, Iraq, Afghanistan, Pakistan and Kazakhstan deep in Soviet Central Asia. Thus it is the easternmost species of the genus Aegilops.

In 1955 The Kyoto University Scientific Expedition to The Karakoram and Hindukush (KUSE) was organized and Drs. Kihara and Yamashita, the members of the expedition, collected a lot of strains of Triticum and Aegilops, in which 179 strains of Ae. squarrosa from 106 habitats were included. Morphological, physiological, genetical and cytological studies were carried out with these collections (Kihara et al. 1965). They pointed out that $A e$. squarrosa, as a collective material, is considerably variable in morphological and physiological properties. Vars. typica and anathera occur throughout the whole distribution area, while vars. meyeri and strangulata are restricted, respectively, to the south-west coast and to south-east coast of Caspian sea, where it is relatively humid in contrast to aridness in the most parts of the area occupied by this species.

After Kihara et al. (1965), almost all of variations of this species were concentrated in the regions around the Elburz Mountains. They found that some strains collected in these regions, especially of vars. meyeri and strangulata were resistant to stripe rust as well as to leaf rust and stem rust. In their successful attempts, Kerber and Dyck (1969) and Dyck and Kerber (1970) could transfer the genes for leaf rust resistance to common wheat from two strains of Ae. squarrosa of KUSE collection. These are the practical examples demonstrating rather easy transfer of the desirable gene to common wheat from its wild relatives through genetic recombination.

As reported in the second paper of this series (Nishikawa et al. 1975) there was intraspecific variation of $\alpha$-amylase isozymes in Ae. squarrosa. The present authors fortunately had an oppotunity of studying $\alpha$-amylase isozymes of germinating seeds of Ae. squarrosa of KUSE collection. Data regarding variation of $\alpha$-amylase isozymes and its geographical distribution will be presented here and discussion will be made about the line of descent of hexaploid wheat and its birthplace.

\section{MATERIALS AND METHODS}

Total sixty strains of Ae. squarrosa were examined in the present study (Table 1). Out of these, 57 strains were sampled from KUSE collection, and the remaining three are laboratory strains, two of them derived from Kyoto University. The collection sites of KUSE material are shown in Table 1. Kihara et al. (1965) showed the number of strains and habitats of Ae. squarrosa collected in eight regions along the route of expedition. Table 2 represents the number of strains in each region of the whole collection along with that sampled for the present study. It is apparent that those strains collected in the regions of Tehran, Gorgan, Pahlavi and Tabriz were sampled in higher rates than those in the other regions. Though this might result in more or 
Table 1. Materials used in the present study and their zymogram patterns

\begin{tabular}{|c|c|c|c|c|c|}
\hline \multirow{2}{*}{$\frac{\begin{array}{c}\text { Strain no. } \\
\text { (KUSE) }\end{array}}{2001-3}$} & \multirow{2}{*}{$\frac{\text { Variety }}{\text { typica }}$} & \multicolumn{2}{|c|}{ Collection site } & \multirow{2}{*}{$\begin{array}{r}\text { Region } \\
\text { Quetta }\end{array}$} & \multirow{2}{*}{$\begin{array}{c}\begin{array}{c}\text { Zymogram } \\
\text { pattern }\end{array} \\
1\end{array}$} \\
\hline & & Quetta, & Pakistan & & \\
\hline 2003-4 & anathera & " & $"$ & $" \prime$ & 1 \\
\hline $2033-1$ & typica & Jaldak, & Afghanistan & Kabul & 1 \\
\hline $2042-2$ & $"$ & Kabul, & " & " & 1 \\
\hline $2058-3$ & interm.* & $\begin{array}{l}\text { Pul-i-Khumri- } \\
\text { Haibak, }\end{array}$ & " & Pul-i-Khumri & 1 \\
\hline $2059-2$ & typica & " & " & $\prime \prime$ & 1 \\
\hline $2092-2$ & $" \prime$ & Maimana-Lamen, & " & Maimana & 1 \\
\hline $2093-4$ & interm. & " & " & " & 1 \\
\hline $2095-2$ & anathera & $\prime \prime$ & " & $\prime \prime$ & 1 \\
\hline $2105-1$ & typica & Ghazvin, & Iran & Tehran & 1 \\
\hline $2106-2$ & " & Karaj, & " & " & 2 \\
\hline $2107-1$ & $" \prime$ & " & $" \prime$ & $\prime \prime$ & 2 \\
\hline $2108-4$ & " & $"$ & $"$ & " & 1 \\
\hline $2109-4$ & $\prime \prime$ & $\prime \prime$ & $" \prime$ & $\prime \prime$ & 1 \\
\hline $2111-7$ & strangulata & Sari-Behshahr, & $" \prime$ & Gorgan & 6 \\
\hline $2112-3$ & " & $\prime$ & $" \prime$ & $"$ & 3 \\
\hline $2115-4$ & $" \prime$ & Behshahr-Gorgan, & $"$ & $" \prime$ & 4 \\
\hline $2118-1$ & " & $"$ & $\prime \prime$ & $" \prime$ & 5 \\
\hline $2119-1$ & " & $\underset{\text { Korgan- }}{\text { Khoshyailagh, }}$ & $"$ & $" \prime$ & 2 \\
\hline $2120-1$ & $" \prime$ & 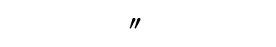 & " & $" \prime$ & 5 \\
\hline $2122-3$ & $"$ & $" \prime$ & " & " & 5 \\
\hline $2123-4$ & $\prime \prime$ & $\prime \prime$ & $" \prime$ & $" \prime$ & 3 \\
\hline 2124 & " & $" \prime$ & $\prime \prime$ & " & 3 \\
\hline $2126-2$ & typica & $\prime \prime$ & $\prime \prime$ & $"$ & 3 \\
\hline $2128-4$ & " & " & $\prime \prime$ & $" \prime$ & 1 \\
\hline $2129-1$ & " & Khoshyailagh, & " & $"$ & 2 \\
\hline 2130 & interm. & " & $\prime \prime$ & " & 2 \\
\hline $2132-9$ & typica & Eiruzkuh, & $"$ & Tehran & 2 \\
\hline $2134-1$ & strangulata & Sari-Behshahr, & $\prime \prime$ & Gorgan & 3 \\
\hline $2135-3$ & " & Behshahr, & $" \prime$ & " & 3 \\
\hline $2136-3$ & $" \prime$ & " & $" \prime$ & $"$ & 3 \\
\hline $2138-4$ & $" \prime$ & Behshahr-Sari & $\prime \prime$ & $" \prime$ & 3 \\
\hline $2139-6$ & " & Behshahr-Chalus & $\prime \prime$ & $\prime \prime$ & 3 \\
\hline $2140-2$ & typica & " & $\prime \prime$ & $" \prime$ & 3 \\
\hline $2141-2$ & " & $\prime$ & $\prime \prime$ & " & 4 \\
\hline $2142-7$ & $"$ & Ramsar, & $\prime \prime$ & Pahlavi & 3 \\
\hline $2144-2$ & meyeri & $"$ & $" \prime$ & " & 4 \\
\hline $2146-2$ & typica & Ramsar-Rasht, & $" \prime$ & $" \prime$ & 4 \\
\hline $2147-1$ & $"$ & " & $" \prime$ & $" \prime$ & 4 \\
\hline $2148-1$ & $\prime \prime$ & Rasht, & $\prime \prime$ & $\prime \prime$ & 4 \\
\hline $2150-1$ & $\prime \prime$ & Pahlavi, & $\prime \prime$ & $\prime \prime$ & 3 \\
\hline
\end{tabular}


Table 1. continued

\begin{tabular}{|c|c|c|c|c|c|}
\hline $\begin{array}{l}\text { Strain no. } \\
\text { (KUSE) }\end{array}$ & Variety & Collection sit & & Region & $\begin{array}{c}\text { Zymogram } \\
\text { pattern }\end{array}$ \\
\hline $2152-1$ & typica & Pahlavi, & Iran & Pahlavi & 4 \\
\hline $2157-2$ & meyeri & Astara, & " & " & 1 \\
\hline $2159-2$ & typica & " & " & $" \prime$ & 4 \\
\hline $2162-6$ & interm. & Ardabil, & " & $\prime \prime$ & $?$ \\
\hline $2163-5$ & $" \prime$ & Ardabil-Surab, & $" \prime$ & $" \prime$ & 2 \\
\hline $2167-2$ & typica & Mahabad, & $" \prime$ & Tabriz & 1 \\
\hline $2168-1$ & " & " & $" \prime$ & " & 1 \\
\hline $2169-1$ & $\prime \prime$ & Mahabad-Rezaiyeh, & $\prime \prime$ & " & 1 \\
\hline $2170-1$ & " & Rezaiyeh-Khoy, & $"$ & " & 1 \\
\hline $2171-6$ & interm. & $\prime$ & $"$ & $"$ & 2 \\
\hline $2172-3$ & " & Khoy, & $"$ & $"$ & 2 \\
\hline $2174-1$ & typica & Khoy-Tabriz, & $" \prime$ & $"$ & 1 \\
\hline $2175-2$ & $"$ & $\begin{array}{l}\text { (mixed in chicken } \\
\text { feed) (Tabriz) }\end{array}$ & $?$ & $?$ & 1 \\
\hline $2176-8$ & $"$ & Tabriz & Iran & Tabriz & 2 \\
\hline $2179-2$ & " & Khoy-Tabriz, & $"$ & " & 7 \\
\hline 2181 & interm. & Chalus & " & Pahlavi & 2 \\
\hline $133^{* *}$ & typica & unknown & $?$ & $?$ & 1 \\
\hline $226^{* *}$ & $\prime \prime$ & Derbent, & Caucasus & & 3 \\
\hline $227 * *$ & $\prime \prime$ & unknown & $?$ & $?$ & 1 \\
\hline
\end{tabular}

* Intermediate type between typica and anathera.

** Laboratory strain.

Table 2. The number of strains of Aegilops squarrosa collected from eight regions in Pakistan, Afghanistan and Iran (KUSE)

\begin{tabular}{lrrrr}
\hline \multirow{2}{*}{ Region } & \multicolumn{5}{c}{ No. of strains } \\
\cline { 2 - 6 } & Whole collection* & for this study \\
\hline Quetta & 15 & $(8.4 \%)$ & 2 & $(13.3 \%) * *$ \\
Kabul & 35 & $(19.6 \%)$ & 2 & $(5.7 \%)$ \\
Pul-i-Khumri & 31 & $(17.3 \%)$ & 2 & $(6.5 \%)$ \\
Maimana & 24 & $(13.4 \%)$ & 3 & $(12.5 \%)$ \\
Tehran & 14 & $(7.8 \%)$ & 6 & $(42.9 \%)$ \\
Gorgan & 23 & $(12.8 \%)$ & 20 & $(87.0 \%)$ \\
Pahlavi & 25 & $(14.0 \%)$ & 12 & $(48.0 \%)$ \\
Tabriz & 9 & $(5.0 \%)$ & 9 & $(100.0 \%)$ \\
unknown & 3 & $(1.7 \%)$ & 1 & $(33.3 \%)$ \\
Total & 179 & $(100.0 \%)$ & 57 & $(31.8 \%)$ \\
\hline
\end{tabular}

* Taken from Kihara et al. (1965).

** Percentage to whole collection. 
less deviation of intraspecific variation, the present authors intended more intensive survey in those regions because of the center of diversity of this species.

Zymogram technique for $\alpha$-amylase of germinating seeds used here was the same as described in the previous paper (Nishikawa and Nobuhara 1971; Nishikawa et al. 1975). In $A e$. squarrosa, as in the other wild grasses, there was seed to seed variation in germination rate. Then, seeds of seven days old after coleorhiza emergence were used for electrophoresis. In order to identify the individual bands the zymogram of mixture of the extracts of the particular ditelosomic line of Chinese Spring and a given strain of Ae. squarrosa was examined.

\section{RESULTS}

1. Variation of $\alpha$-amylase isozymes in Ae. squarrosa

As illustrated in Fig. 1, seven different patterns of $\alpha$-amylase zymogram (Ams 1-7) were detected in 60 strains of Ae. squarrosa tested here. Frequencies with which
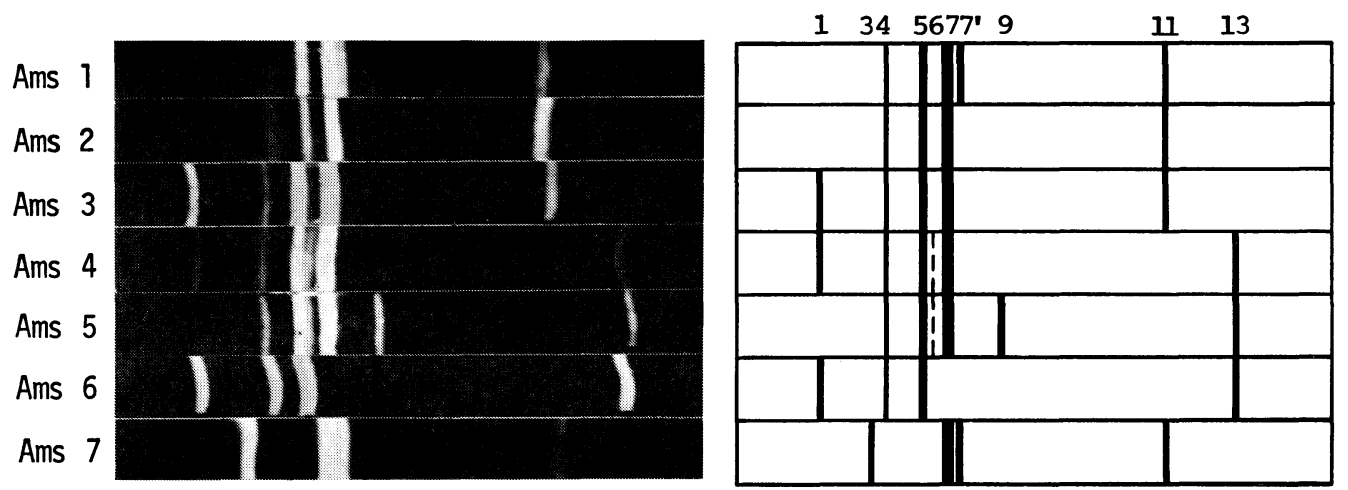

Fig. 1. Seven zymogram patterns of $\alpha$-amylase in germinating seed of Aegilops squarrosa.

Table 3. The number of strains for seven zymogram patterns of $\alpha$-amylase of germinating seed in Aegilops squarrosa

\begin{tabular}{|c|c|c|c|c|c|c|c|c|c|}
\hline \multirow{2}{*}{\multicolumn{2}{|c|}{$\begin{array}{c}\text { Zymogram } \\
\text { pattern }\end{array}$}} & \multicolumn{5}{|c|}{ eu-squarrosa } & \multirow{2}{*}{$\begin{array}{l}\text { strang. } \\
\text { strang. }\end{array}$} & \multirow{2}{*}{\multicolumn{2}{|c|}{ Total }} \\
\hline & & typica & interm.* & anathera & meyeri & Subtotal & & & \\
\hline \multirow[t]{7}{*}{$\mathrm{Ams}$} & 1 & 17 & 2 & 2 & 1 & 22 & 0 & 22 & $(36.7 \%)$ \\
\hline & 2 & 5 & 6 & 0 & 0 & 11 & 1 & 12 & $(20.0 \%)$ \\
\hline & 3 & 5 & 0 & 0 & 0 & 5 & 8 & 13 & $(21.7 \%)$ \\
\hline & 4 & 6 & 0 & 0 & 1 & 7 & 1 & 8 & $(13.3 \%)$ \\
\hline & 5 & 0 & 0 & 0 & 0 & 0 & 3 & 3 & $(5.0 \%)$ \\
\hline & 6 & 0 & 0 & 0 & 0 & 0 & 1 & 1 & $(1.7 \%)$ \\
\hline & 7 & 1 & 0 & 0 & 0 & 1 & 0 & 1 & $(1.7 \%)$ \\
\hline \multicolumn{2}{|c|}{ Total } & 34 & 8 & 2 & 2 & 46 & 14 & 60( & $(100.1 \%)$ \\
\hline
\end{tabular}

* Intermediate type between typica and anathera. 
seven zymogram patterns occurred are represented in Table 3. Ams 1 was the most prevailing pattern (36.7\%), followed by Ams 3 (21.7\%), Ams $2(20.0 \%)$ and Ams $4(13.3 \%)$, and others (Ams 5, 6 and 7) were very rare. In var. typica, Ams 1 was most frequent, and Ams 2, 3 and 4 occurred with almost equal frequencies. While, Ams 2, though small sample size, happened with the higher frequency than Ams 1 in the intermediate type between vars. typica and anathera. Only Ams 1 was found in var. anathera, and Ams 1 and 4 in var. meyeri. Because of too small sample size, nothing could be mentioned about these two varieties. Fourteen strains of ssp. strangulata were different from ssp. eu-squarrosa in occurrence of zymogram patterns, i.e. Ams 3 was predominant, followed by Ams 5, and none of Ams 1 and 7 could be detected.

There were total ten different isozyme bands detected through seven zymogram patterns. The individual bands were identified as Band 1, 3, 4, 5, 6, 7, 7', 9, 11 and 13 of Chinese Spring, respectively. Band 6 was minor and poorly reproducible. Four to six isozyme bands appeared in each of seven zymogram patterns. Interestingly, all the isozyme bands of Ae. squarrosa were those detected in hexaploid wheat. Var. strangulata was different from other varieties in that Band $7^{\prime}$ was absent, but Band 9 present. Band 11 and 13 occurred alternatively. Band 1, 7 and 11 are known in Chinese Spring to be encoded by the respective genes on chromosome 6D and 7D (Nishikawa and Nobuhara 1971; Nishikawa et al. 1976). Then, the zymogram with these three bands would be expected in $A e$. squarrosa, and Ams 3 was the only zymogram pattern that satisfied the expectation. Band 13 found in three zymogram patterns, Ams 4, 5 and 6, was identical with the band known to be specified by the gene on chromosome $7 \mathrm{~A}$, and Band 3 of Ams 7 identical with the one encoded by the gene on chromosome $6 \mathrm{~B}$, respectively, in Chinese Spring (Nishikawa and Nobuhara 1971).

Table 4. Percentage appearance of each band of $\alpha$-amylase isozyme in four varieties and one intermediate type of Aegilops squarrosa

\begin{tabular}{|c|c|c|c|c|c|c|c|}
\hline \multirow{2}{*}{$\begin{array}{l}\text { Band } \\
\text { No. }\end{array}$} & \multicolumn{5}{|c|}{ eu-squarrosa } & \multirow{2}{*}{$\begin{array}{l}\text { strang. } \\
\text { strang. }\end{array}$} & \multirow{2}{*}{ Total } \\
\hline & typica & interm.* & anathera & meyeri & Subtotal & & \\
\hline 1 & $32.3 \%$ & $0 \%$ & $0 \%$ & $50.0 \%$ & $26.1 \%$ & $71.4 \%$ & $36.7 \%$ \\
\hline 3 & 2.9 & 0 & 0 & 0 & 2.2 & 0 & 1.7 \\
\hline 4 & 97.1 & 100.0 & 100.0 & 100.0 & 97.8 & 100.0 & 98.3 \\
\hline 5 & 97.1 & 100.0 & 100.0 & 100.0 & 97.8 & 100.0 & 98.3 \\
\hline 6 & 2.9 & 0 & 0 & 0 & 2.2 & 28.6 & 8.3 \\
\hline 7 & 100.0 & 100.0 & 100.0 & 100.0 & 100.0 & 92.9 & 98.3 \\
\hline $7^{\prime}$ & 52.9 & 25.0 & 100.0 & 50.0 & 50.0 & 0 & 38.3 \\
\hline 9 & 0 & 0 & 0 & 0 & 0 & 21.4 & 5.0 \\
\hline 11 & 82.4 & 100.0 & 100.0 & 50.0 & 84.8 & 64.3 & 80.0 \\
\hline 13 & 17.6 & 0 & 0 & 50.0 & 15.2 & 35.7 & 20.0 \\
\hline PI** & 0.087 & 0.019 & 0 & 0.100 & 0.077 & 0.110 & 0.098 \\
\hline
\end{tabular}

* Intermediate type between typica and anathera.

** Polymorphic index (Marshal and Allard 1970).

$\mathrm{PI}=\sum p_{i}\left(1-p_{i}\right) / n$, where $p_{i}$ : appearance of the $i$ th band (in decimal fraction), $n$ : total number of the bands detected. 


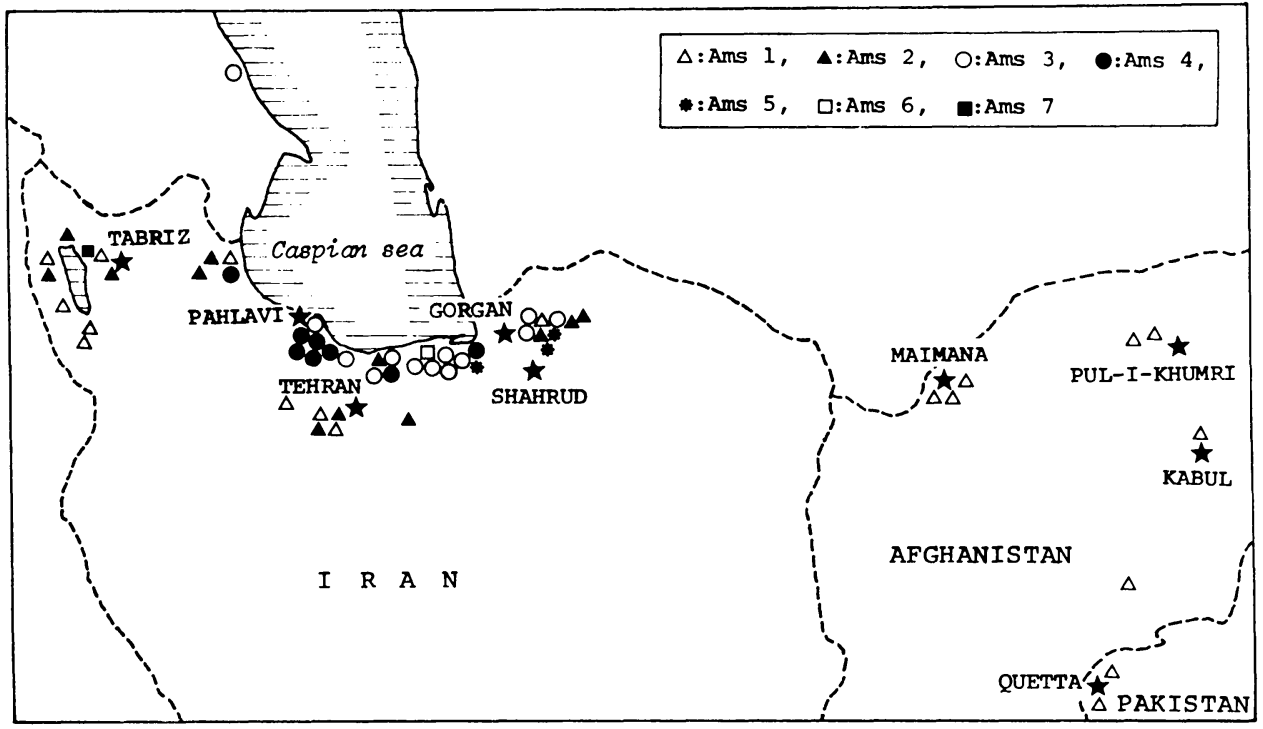

Fig. 2. Map showing distribution of seven zymogram patterns of $\alpha$-amylase in germinating seed of Aegilops squarrosa.

Percentage appearance of the individual bands was summarized in Table 4. Band $4,5,7$ and 11 occurred in high percentage, and Band 1 and $7^{\prime}$ in moderate rate. Variation in ssp. eu-squarrosa was, as a whole, not largely different from that of ssp. strangulata. Polymorphic index (Marshal and Allard 1970) adopted as a measure of zymogram variability was shown for each variety in the same table. Vars. meyeri (though small sample size) and strangulata showed considerably high value.

\section{Geographical distribution of zymogram patterns}

Figure 2 is the map showing the collection sites of those strains used here, marked with the respective zymogram patterns. In the eastern part of the distribution area, Afghanistan and Pakistan, one of seven patterns, Ams 1 was exclusively found irrespective of varieties. In addition, Ams 1 and Ams 2, the latter differing from the former in absence of Band $7^{\prime}$ were detected in the regions of Tehran and Tabriz. These patterns were also sporadically found in north of Shahrud and near Astara. In the narrow belt of the south coast of Caspian sea, where vars. meyeri and strangulata inhabit, the particular zymogram patterns were concentrated; Ams 3 towards the east and Ams 4 towards the west.

\section{DISCUSSION}

Kihara and Tanaka (1958) and Kihara et al. (1965) reported the results of morphological, physiological, genetical and cytological studies of Ae. squarrosa of KUSE collection. They pointed out that Ae. squarrosa was rich in variation with respect to morphological and physiological characters, and that almost all the variations were concentrated in the districts around the Elburz Mountains. Zohary et al. (1969) aslo recognized south 
Table 5. Polymorphic index as a measure of intraspecific variability in wheat and its relatives

\begin{tabular}{|c|c|c|}
\hline Species & $\alpha$-Amylase* & Esterase** \\
\hline \multicolumn{3}{|l|}{ Einkorn (AA) } \\
\hline boroticum & 0.068 & 0.000 \\
\hline monococcum & 0.034 & 0.016 \\
\hline \multicolumn{3}{|l|}{ Emmer (AABB) } \\
\hline dicoccoides & 0.102 & 0.075 \\
\hline \multicolumn{3}{|l|}{ turgidum } \\
\hline hulled & 0.102 & 0.002 \\
\hline naked & 0.041 & 0.030 \\
\hline \multicolumn{3}{|l|}{ Timopheevi (AAGG) } \\
\hline araraticum & 0.014 & 0.125 \\
\hline timopheevi & 0.000 & 0.101 \\
\hline \multicolumn{3}{|l|}{ Dinkel (AABBDD) } \\
\hline aestivum & 0.028 & 0.017 \\
\hline \multicolumn{3}{|l|}{ Aegilops } \\
\hline speltoides (SS) & 0.176 & - \\
\hline longissima $\left(\mathrm{S}^{1} \mathrm{~S}^{1}\right)$ & 0.105 & - \\
\hline sharonensis $\left\langle S^{1} S^{1}\right\rangle$ & 0.076 & - \\
\hline bicornis $\left(\mathrm{S}^{\mathrm{b}} \mathrm{S}^{\mathrm{b}}\right)$ & 0.051 & - \\
\hline squarrosa (DD) & 0.098 & 0.077 \\
\hline
\end{tabular}

* Taken from Nishikawa and Nobuhara (1971), Nishikawa et al. (unpublished).

** Calculated based on Nakai (1978).

Caspian area as an area of the widest ecological amplitude and morphological diversity in Ae. squarrosa. Furuta et al. (1975) reported variation in DNA content per nucleus within this diploid species. In addition, considerable intraspecific variations were observed in it with respect to esterase isozymes (Nakai 1973; Jaaska 1980) and aspartate aminotransferase isozymes (Jaaska 1976). Polymorphic index (PI) adopted here as a measure of isozyme polymorphism was 0.098 for $A e$. squarrosa as a whole, while 0.077 for ssp. eu-squarrosa and 0.110 for ssp. strangulata with respect to $\alpha$-amylase isozyme (Table 4). It is apparent that the latter is more variable than the former. Consistently with Kihara et al. (1965) ample variation of $\alpha$-amylase isozymes was found in south Caspian area, i.e. PI value being 0.112 for the region of Gorgan, 0.099 for Pahlavi, 0.047 for Tabriz and no variation in the regions of Quetta, Pul-i-Khumri and Maimana. Among related species of wheat, Ae. squarrosa seems to be moderate in $\alpha$-amylase isozyme variability (Table 5). Mitra and Bhatia (1971) showed greater variation in those enzymes like esterase which had broad substrate specificity and like alcohol dehydrogenase which was not essential for normal metabolic process, in contrast to those enzymes like malate dehydrogenase, glutamate dehydrogenase and isocitrate dehydrogenase which had definite substrate specificity. $\alpha$-Amylase isozymes studied here were evidently more variable, with an exception for $T$. timopheevi, than esterase 
isozymes reported by Nakai (1979a), and not so much as isozymes of peroxidase that is one of the most variable enzymes.

From the studies in hexaploid wheat (Nishikawa and Nobuhara 1971; Nishikawa et al. 1975, 1976, 1978) Band 1 through Band 9 on the $\alpha$-amylase zymogram of $A e$. squarrosa could be assumed to be encoded by the genes on chromosome $6 \mathrm{D}$, while Band 11 and 13 by those on chromosome 7D. All the seven zymogram patterns of Ae. squarrosa had, without exception, three to five bands of $6 \mathrm{D}$ isozymes and one of $7 \mathrm{D}$ isozymes, respectively. This, together with the results of comparable works in related species (Nishikawa et al. unpublished) means that the isozymes of either 6D and 7D are indispensable for seed germination in wheat group. As in tetra- and hexaploid wheat, the isozymes of group 6 were more variable than those of group 7 in Ae. squarrosa. Moreover, the fact that Band 3 and 13, which were known in common wheat to be encoded by the respective genes on chromosome $6 \mathrm{~B}$ and $7 \mathrm{~A}$, were found in the $\mathrm{D}$ genome carrier implies that similar variation, or parallel mutation could have taken place in the related genomes. Jaaska (1976) presented the similar view with respect to the genes for aspartate aminotransferase isozymes.

Because the zymogram pattern with all three $\mathrm{D}$ genome dependent $\alpha$-amylase isozyme bands, Band 1, 7 and 11, were most prevailing in hexaploid wheat (Nishikawa and Nobuhara 1971; Nishikawa et al. unpublished), it is reasonably inferred that the genes for these isozymes were introduced into hexaploid wheat by the genome $\mathrm{D}$ having the $\alpha$-amylase zymogram pattern, Ams 3. As evident from Fig. 2, Ams 3 distributed densely in the region of Gorgan, near the south-east corner of Caspian sea, extending to the region of Pahlavi and farther to Derbent, Caucasus. It is significant that only one strain of Caucasus origin examined in the present study was of Ams 3. Accordingly, it can be concluded based on $\alpha$-amylase isozyme variation that the main line of descent of hexaploid wheat has originated in the narrow belt from the south-east corner of Caspian sea to Caucasus. Tsunewaki (1966) studied waxiness in Ae. squarrosa and considered the mountainous region near to the south-west coast of Caspian sea as the birthplace of common wheat. Tanaka (1975) thought that hexaploid wheat has originated in Caucasus. In addition, based on variation of esterase isozyme, Nakai (1979b) was of opinion that common wheat has arisen in the region of the south-west Caspian belt to Tsanscaucasus. In his latest paper, Jaaska (1980) showed that some of strains of ssp. strangulata of different geographical origin (Transcaucasus, Iran and Turkmenistan) best fitted the donor of the D genome to hexaploid wheat. Summarizing the reports of the previous authors, the birthplace of hexaploid wheat could be restricted to Transcaucasus and/or south-west coastland of Caspian sea. However, the result of the present study strongly indicates that in addition to the regions just mentioned, south-east coastland of Caspian sea should be considered as the possible region where the main line of descent of hexaploid wheat has originated.

Caspian coastland in Iran is wettest in the area occupied by Ae. squarrosa. According to a climatological literature (Hatakeyama 1964), the average annual rainfall exceeds 2,000 mm in Gilan and Mazandaran, while it decreases eastwards to 500 to $600 \mathrm{~mm}$ in the coastal plain of Gorgan, where Ams 3 of $\alpha$-amylase zymogram is most concentrated, and most of precipitation comes from October to March in this region. On the 
other hand, temperature condition is also not so severe as destroying wild grasses. In view of such rather favorable climatic conditions and luxuriant growth of Ae. squarrosa observed in Gorgan by Kihara et al. (1965), the region near to the south-east corner of Caspian sea could be considered in ecological aspect as a possible birthplace of hexaploid wheat.

In our previous report (Nishikawa 1973; Nishikawa et al. 1975), Ams 3 was detected in var. strangulata only. Now that it has been detected even in var. typica (Table 1, 3 ), it is not, if more likely, pertinent to conclude that the D genome donor to the main line of hexaploid wheat was var. strangulata of Ae. squarrosa.

There were, however, two variant patterns of $\alpha$-amylase zymogrom in hexaploid wheat involving the $\mathrm{D}$ genome dependent isozymes, the one being absence of Band 1 in macha subletschchumicum and some other cultivars of common wheat, and the other absence of Band 11 in macha palaeoimereticum (Nishikawa and Nobuhara 1971). It should be noticed that both variant types were represented by macha, whose origination had been discussed by some authors. Jakubziner (1959) suggested that $T$. palaeocolchicum contributed the genomes A and B to macha, and Swaminathan (1966) proposed independent amphiploid origin of macha from T. palaeocolchicum and Ae. squarrosa. Jaaska (1978) studied aromatic alcohol dehydrogenase isozymes and considered Swaminathan's proposal unlikely. Dekaprelevich (1961) considered a common origin of macha and spelta. Tsunewaki (1968), however, based on the facts that macha was only hexaploid wheat carrying the chlorosis gene, $C h_{1}$, and that no strain of Ae. squarrosa carried $c h_{2}$, showed possibility of introgression of the genes, $C h_{1}$ and $q$ of dicoccoides or dicoccum into Asian T. aestivum. Johnson (1972) found a distinct and uniform protein electrophoresis pattern in five out of six accessions of macha and suggested its origin independent of the most of the primitive hexaploid wheat. As cited above, origin of macha is still controversial. The present study, however, may furnish a view of origin of macha. Because variation due to the genome $\mathrm{D}$ of hexaploid wheat could not be introduced from tetraploid wheat, $\alpha$-amylase isozyme variation in macha can not be explained by Tsunewaki's hypothesis. If $\alpha$-amylase isozyme variations occurred de novo in macha, then two possibilities, (1) mutational change and (2) amphiploidization independent from the main line of descent of hexaploid wheat between Emmer and $A e$. squarrosa of $\alpha$-amylase zymogram pattern of, for example, Ams 5 , though excluded by Tsunewaki, should be considered again.

\section{ACKNOWLEDGMENTS}

The authors wish to express their sincere thanks to Dr. M. Tanaka, Kyoto University for providing us with materials used in this study.

\section{LITERATURE CITED}

Dekaprelevich, L. L., 1961 Die Art Triticum macha Dek. et Men. im Lichte neuester Untersuchungen über die Herkunft der hexaploiden Weizen. Z. Pflanzüchtg 45: 17-30.

Dyck, P. L., and E. R. Kerber, 1970 Inheritance in hexaploid wheat of adult plant leaf rust 
resistance derived from Aegilops squarrosa. Can. J. Genet. Cytol. 12: 175-180.

Furuta, Y., K. Nishikawa, and T. Makino, 1975 Intraspecific variation of nuclear DNA content in Aegilops squarrosa L. Japan. J. Genetics 50: 257-263.

Hatakeyama, H., 1964 "Climate in Asia (in Japanese)" pp. 577, Kokin Shoin, Tokyo.

Jaaska, V., 1976 Aspartate aminotransferase isozymes in the polyploid wheats and their diploid relatives. On the origin of tetraploid wheats. Biochem. Physiol. Pflanzen 170: 159-171.

Jaaska, V., 1978 NADP-dependent aromatic alcohol dehydrogenase in polyploid wheats and their diploid relatives. On the origin and phylogeny of polyploid wheats. Theor. Appl. Genet. 53: 209-217.

Jaaska, V., 1980 Electrophoretic survey of seedling esterases in wheats in relation to their phylogeny. Theor. Appl. Genet. 56: 273-284.

Jakubziner, M. M., 1959 New wheat species. Proc. 1st Int. Wheat Genet. Symp. (Winnipeg): 207-217.

Johnson, B. L., 1972 Protein electrophoretic profiles and the origin of the B genome of wheat. Proc. Natl. Acad. Sci. USA 69: 1398-1402.

Kerber, E. R., and P. L. Dyck, 1969 Inheritance in hexaploid wheat of leaf rust resistance and other characters derived from Aegilops squarrosa. Can. J. Genet. Cytol. 11: 639-647.

Kihara, H., and M. Tanaka, 1958 Morphological and physiological variation among Aegilops squarrosa strains collected in Pakistan, Afghanistan and Iran. Preslia 30: 241-251.

Kihara, H., K. Yamashita, and M. Tanaka, 1965 Morphological, physiological, genetical and cytological studies in Aegilops and Triticum collected from Pakistan, Afghanistan and Iran. Results of The Kyoto University Scientific Expedition to The Karakoram and Hindukush, 1955, 1: 1-118.

Marshal, D. R., and R. W. Allard, 1970 Isozyme polymorphism in natural populations of Avena fatua and $A$. barbata. Heredity 25: 373-382.

Mitra, R., and C. R. Bhatia, 1971 Isozymes and polyploidy I. Qualitative and quantitative isozyme studies in the Triticinae. Genet. Res. Camb. 18: 57-69.

Nakai, Y., 1973 Isozyme variations in Aegilops and Triticum. II. Esterase and acid phosphatase isozymes studied by the gel isoelectrofocusing method. Seiken Ziho 24: 45-73.

Nakai, Y., 1978 Genetical studies of the variations of esterase isozymes in Aegilops and Triticum. Doctor Thesis, Fac. Agr. Kyoto Univ.: 157.

Nakai, Y., 1979a The origin of the tetraploid wheats revealed from the study on esterase isozymes. Proc. 5th Int. Wheat Genet. Symp. (New Delhi): 108-119.

Nakai, Y., 1979b Isozyme variations in Aegilops and Triticum. IV. The origin of the common wheats revealed from the study on esterase isozymes in synthesized hexaploid wheats. Japan. J. Genetics 54: 175-189.

Nishikawa, K., 1973 Alpha-amylase isozymes and phylogeny of hexaploid wheat. Proc. 4th Int. Wheat. Genet. Symp. (Columbia, Mo.): 851-855.

Nishikawa, K., Y. Furuta, and H. Goshima, 1975 Genetic studies of $\alpha$-amylase isozymes in wheat. II. Reconstituted AABB tetraploid, Aegilops squarrosa and their AABBDD hexaploid. Japan. J. Genetics 50: 409-416.

Nishikawa, K., Y. Furuta, Y. Hina, and S. Fuji, 1978 Some differential properties of alpha-amylase isozymes in growing and germinating seed of wheat. Wheat Inf. Serv. 47, 48: 47-48.

Nishikawa, K., Y. Hina, S. Oonishi, and Y. Furuta, 1976 The D genome dependent isozymes of $\alpha$-amylase in wheat. Wheat Inf. Serv. 41, 42: 8.

Nishikawa, K., and M. Nobuhara, 1971 Genetic studies of $\alpha$-amylase isozymes in wheat. I. Location of genes and variation in tetra- and hexaploid wheat. Japan. J. Genetics 44: $345-$ 353.

Swaminathan, M. S., 1966 Mutational analysis of the hexaploid Triticum complex. Proc. 2nd Int. Wheat Genet. Symp. (Lund): 418-437.

Tanaka, M., 1975 The origin of cultivated plants, especially on the evolution of wheat. Biological Science (Tokyo) 27: 30-42.

Tsunewaki, K., 1966 Comparative gene analysis of common wheat and its ancestral species. II. 
Waxiness, growth habit and awnedness. Japan. J. Bot. 19: 175-229.

Tsunewaki, K., 1968 Origin and phylogenetic differentiation of common wheat revealed by comparative gene analysis. Proc. 3rd Int. Wheat Genet. Sym. (Canberra): 71-85.

Zohary, D., J. R. Harlan, and A. Vardi, 1969 The wild progenitors of wheat and their breeding value. Euphytica 18: 58-65. 